\title{
Metode Learning by Playing pada Aplikasi Perangkat Lunak Bahasa Inggris Dasar Usia Taman Kanak-Kanak
}

\author{
Maya Rini Handayani \\ Universitas Islam Negeri Walisongo Semarang
}

\begin{abstract}
Starting in 2016, It is compulsory for every child in Indonesia to learn in kindergarten school for 1 year according to the rules of UNESCO. This rule makes a lot of kindergartens providing alternative extra curricular such as Basic English extracurricular to attract parents to educate their children at the school. But unfortunately sometimes the school neglect the quality of school teachers who will teach the English extracurricular. It is make the writer provides an alternative solution for the kindergarten school to make an Basic English application. The created applications is the application of a basic level of English language by using the learning by playing method as an alternative learning. Method of learning by playing is a method of studying subjects for kindergarten children using the game. Therefore, application of Basic English is made using such methods. The benefits of the basic English application using the method of learning by playing are 1) to help teachers who teach basic English to minimize the errors in teaching, 2) to alleviate expenses to recruit new English teachers, and 3) to save the youth Muslim generation'sintelligence from an early age.
\end{abstract}

Abstrak: Mulai tahun 2016, diwajibkan bagi setiap anak Indonesia untuk belajar di sekolah Taman Kanak-kanak (TK) selama 1 tahun sesuai aturan UNESCO. Aturan ini membuat banyak sekolah TK memberikan alternatif ekstra kurikuler (ekskul) seperti ekskul bahasa Inggris untuk menarik minat orang tua untuk menyekolahkan anak mereka di sekolah tersebut. Namun sayangnya kadang kala sekolah mengabaikan kualitas pengajar yang akan mengajar ekskul tersebut. Alasan inilah yang membuat pengabdi memberikan solusi alternatif bagi sekolah TK tersebut dengan membuat sebuah aplikasi. Aplikasi yang di buat adalah aplikasi bahasa Inggris tingkat dasar dengan menggunakan metode learning by playing sebagai alternatif pembelajaran. Metode learning by playing adalah metode mempelajari mata pelajaran bagi anak 
TK dengan menggunakan permainan. Oleh sebab itu aplikasi pembelajaran bahasa Inggris tingkat dasar ini dibuat menggunakan metode tersebut. Manfaat dari aplikasi bahasa Inggris menggunakan metode learning by playingadalah 1) membantu guru yang mengajar ekskul agar kesalahan dalam pengajaran dapat diminimalisir, 2) meringankan biaya pengeluaran untuk merekrut guru baru berpendidikan bahasa Inggris, dan 3) menyelamatkan kecerdasan generasi muda Islam sejak dini.

Kata Kunci: belajar, bermain, taman kanak-kanak, bahasa Inggris dasar

\section{PENDAHULUAN}

Pendidikan di Indonesia dibagi menjadi 2 kategori yaitu pendidikan dasar dan menengah. Pemerintah sudah membebaskan biaya sekolah atau SPP (Sumbangan Pembinaan Pendidikan) untuk pendidikan dasar. Pendidikan dasar di Indonesia dimulai dari sekolah dasar (SD) hingga sekolah menengah pertama (SMP). Sedangkan Taman kanak-kanak (TK) adalah jenjang pendidikan anak usia dini (PAUD) yang mempunyai rentang usia 2 hingga 6 tahun. Pendidikan TK merupakan pendidikan formal yang tidak wajib diikuti oleh anak-anak sebelum masuk SD.

Pada tahun 2016, UNESCO mewajibkan setiap anak untuk bersekolah paling tidak selama 1 tahun sebelum masuk jenjang sekolah dasar ${ }^{1}$. Oleh sebab itu pada tahun ini, pemerintah mewacanakan untuk menerapkan peraturan wajib bersekolah TK sebelum masuk SD (sesuai dengan peraturan UNESCO). Banyaknya masyarakat yang ingin menyekolahkan anaknya sedini mungkin, menyebabkan banyak bermunculan sekolah PAUD di Indonesia. Bahkan di wilayah yang dijadikan pengabdian yaitu di lingkungan Peterongan Tengah,terdapat lebih dari 10 TK. Masing-masing TK tersebut hanya berjarak maksimal $1 \mathrm{~km}$ (satu kilometer). Kesepuluh TK tersebar dalam jenis TK Islam, umum maupun non Islam. TK tersebut antara lain ABA 62, ABA 5, ABA 4, Gotong Royong, Kuncup Harapan, Pertiwi, PGRI, DAQU, Kuncup Sari, Sultan Agung 1, Nurul Suja, dan TK B Kristen Kristiana.

Adanya kewajiban untuk sekolah satu tahun tersebut, menyebabkan setiap TK berusaha memberikan kurikulum terbaik. Selain pelajaran umum yang

\footnotetext{
Anonim, 2015, Mulai 2016 Wajib TK Sebelum Masuk SD, http://www.jpnn.com/read/2015/06/19/310452/Mulai-2016,-Wajib-TK-Sebelum-Masuk-SD, diakses 2 Maret 2016
} 
diberikan, banyak TK juga memberikan ekstrakurikuler (ekskul) seperti memasak (cooking class), menggambar, melukis (finger painting, hand painting), menari, pencak silat bahkan komputer dan bahasa Inggris. Sayangnya, keinginan untuk memberikan kurikulum ideal tersebut kadang kala tidak berbanding lurus dengan sumber daya manusia (SDM) yang dimiliki. Banyak TK yang memaksakan SDM yang dimiliki untuk mengajar mata pelajaran (mapel) yang tidak sesuai dengan latar belakang pendidikan pengajar.

TK yang dijadikan sebagai obyek pengabdian, memberikan ekskul mapel bahasa Inggris tingkat dasar. Akan tetapi sangat disayangkan pengajar mapel tersebut bukanlah pendidik yang mempunyai latar belakang sarjana bahasa Inggris. Hal ini sangat berbahaya apabila guru salah dalam memberikan pelajaran baik dalam mengeja (spelling), cara pengucapan (pronounciation) dan bagaimana menterjemahkan (translate). Anak TK memiliki kecerdasan penyerapan ingatan yang luar biasa dan akan berbahaya apabila pelajaran yang diberikan sudah salah dari awal pembelajaran (usia dini). Bukan bermaksud merendahkan keilmuan guru TK tersebut namun akan lebih baik jika kehati-hatian dalam menyebarkan ilmu sangat diperhatikan.

\section{PEMBAHASAN HASIL PENGABDIAN}

Di Indonesia, sekolah pada umumnya masih menggunakan metode pembelajaran konvensional. Metode pembelajaran konvensional adalah pengajar (guru atau dosen) mengajar pelajaran di kelas dengan menggunakan cara berceramah, berdiskusi dan tanya jawab baik menggunakan alat bantu berupa OHP atau/dan LCD proyektor. Dalam berceramah, pengajar biasanya menjelaskan materi dan memberikan contoh terlebih dahulu kemudian disusul dengan soal latihan. Soal latihan diberikan untuk mengukur daya tangkap dan nalar siswa.

Pada mapel bahasa Inggris di kegiatan ekskul pada sekolah TK yang dijadikan obyek pengabdian, guru memberikan contoh cara pengucapan sebuah kata dalam bahasa Inggris kemudian siswa menirukan. Kondisi ini yang harus diwaspadai sebab jika guru salah dalam mengucapkan sebuah kata maka kata tersebut akan selalu diingat hingga siswa dewasa. Hal ini bisa berakibat fatal jika siswa tersebut dewasa nantinya. Mereka hanya akan menjadi pendengar pasif dan bukan pembicara aktif menggunakan bahasa Inggris.

Kelemahan guru dalam mengajar sebenarnya dapat diselesaikan dengan memberikan kursus bahasa Inggris bagi para guru tersebut. Akan tetapi solusi tersebut dapat saja menimbulkan masalah baru, yaitu masalah finansial baik bagi 
guru secara pribadi maupun sekolah. Tidak semua sekolah TK mempunyai pendanaan atau dana operasional yang cukup. Seringkali sekolah TK membebaskan pembebanan biaya pendidikan atau SPP apabila siswa adalah anak yatim atau yatim piatu atau dari keluarga kurang mampu dengan bukti surat dari kelurahan.Peringanan biaya pendidikan semakin membuat dana operasional sekolah tersebut menjadi berkurang. Berkurangnya dana operasional menyebabkan sedikitnya pendapatan atau gaji yang diberikan pihak sekolah kepada guru-gurunya.

Minim atau rendahnya gaji yang diterima membuat para guru akan berpikir ulang jika harus mengambil kursus bahasa Inggris. Minimnya dana operasional juga tidak memungkinkan pihak sekolah untuk mengkursuskan bahasa Inggris bagi gurunya. Sulitnya pilihan tersebut membuat banyak sekolah TK terpaksa memaksakan kemampuan guru yang tidak sesuai dengan bidang ilmu untuk mengajar kelas ekskul. Kondisi ini membuat pengabdimencari solusi yang terbaik bagi sekolah, guru dan siswa yang belajar ekskul bahasa Inggris.

Solusi untuk permasalahan diatasadalah dengan melakukan perubahan pada metode pembelajarannya. Jika awalnya menggunakan metode konvensional maka hendaknya sekolah sudah mulai berpikir untuk menggunakan software (perangkat lunak) sebagai alat bantu.Software ini berbentuk aplikasi bahasa Inggris yang akan diajarkan pada siswa TK tersebut. Aplikasi tersebut berisi materi bahasa Inggris tingkat dasar yang disesuaikan dengan kurikulum sekolah tersebut. Namun aplikasi software saja belum cukup untuk menyelesaikan permasalahan tersebut. Hanya bergantung padasoftware tidak akan menyelesaikan masalah jika guru tidak pula merubah metode pembelajarannya. Metode pembelajaran yang dapat mendukung aplikasi software bahasa Inggris tingkat dasar ini adalah metode learning by playing.

Metode learning by playingatau metode belajar melalui bermain atau permainan adalah sebuah metode yang digunakan dalam pendidikan untuk menggambarkan bagaimana seseorang atau seorang anak dapat belajar untuk memahami dunia di sekitar mereka melalui bermain atau permainan. Melalui bermain seseorang atau anak-anak dapat mengembangkan keterampilan sosial dan kemampuan kognitifnya, seseorang atau anak-anak dapat matang secara emosional, dan mendapatkan kepercayaan diri yang dibutuhkan untuk terlibat dalam pengalaman dan lingkungan yang baru.

Inti dari metode ini adalah seseorang atau anak-anak belajar melalui permainan, berada bersama orang lain atau anak lain, aktif terlibat dalam permainan, mengeksplorasi diri dalam memperoleh pengalaman baru, berbicara untuk diri mereka sendiri, mampu berkomunikasi dengan orang lain atau anak 
lain, mampu menghadapi tantangan fisik dan mental, berani untuk menampilkan diri dalam melakukan hal-hal baru, mau untuk sering berlatih dan mengulang keterampilan dan merasa senang dengan semua kegiatan yang dilibatinya ${ }^{2}$.Kegiatan pengabdian ini diawali dengan mencari data untuk memperoleh keabsahan data atau/dan informasi yang dikumpulkan. Pada proses pengumpulan data, diperoleh data bahwa TK yang dijadikan obyek pengabdian memang belum mempunyai guru bahasa Inggris yang sesuai dengan bidang keilmuan. Keterbatasan dana operasional sekolah juga memberikan andil dalam ketiadaan usaha untuk meningkatkan kemampuan bahasa Inggis pengajar melalui kursus baik kursus reguler atau pribadi.Terdapat 5 langkah dalam mewujudkan kegiatan pengabdian ini di sekolah tersebut, yaitu networking (kerja sama), perancangan dan pengkodingan, pengujian, pelatihan guru, siswa dan sosialisasi orang tua/wali siswa serta yang terakhir adalah monitoring. Berikut ini adalah penjelasan dari masing-masing langkah.

Tahap pertama adalah melakukan networking (menjalin kerjasama) dengan pihak sekolah yaitu yayasan dan kepala sekolah. Kerjasama ini diharapkan agar para pemegang kebijakan di sekolah dan pelaku kegiatan pengabdianyaitu pengabdi, ikut terlibat secara aktif dengan memberikan bantuan baik moral maupun material selama program berlangsung. Jalinan kerja sama tersebut berguna untuk menyatukan visi dan misi antara pengabdi dengan pihak sekolah.

Pihak sekolah berfungsi menjembatani antara pengabdi dengan guru-guru yang akan menggunakan aplikasi tersebut. Selain guru, pihak sekolah juga berkewajiban menjadi penghubung antara pengabdi dengan orang tua atau wali siswa yang akan menjadi pengguna langsung aplikasi bahasa Inggris dasar ini di rumah beserta putra putrinya. Pada kerja sama ini pengabdi juga menjelaskan bahwa pelaksanaan kegiatan pengabdian (KPD) dilaksanakan kurang lebih selama 4 bulan dimulai dari bulan April dan berakhir bulan Juli 2016.

Empat bulan waktu pengabdian tidak hanya digunakan untuk implementasi dan pendampingan saja namun meliputi kegiatan menjalin kerja sama, perancangan, pengkodingan/pembuatan aplikasi, pengujian, editing atau perbaikan aplikasi hingga pelatihan/implementasi aplikasi menggunakan metode learning by playing dan sosialisasi terhadap orang tua atau wali siswa. Tahap kedua,

Perancangan dan Pengkodingan. Tahap awal perancangan dilakukan oleh pengabdi sendiri. Dimulai dari sketsa gambar latar sebanyak 2 buah dilanjutkan rancangan manual aplikasi dari scene per scene. Perancangan juga meminta saran

2 Anonim, 2016, Learning Through Play, https://en.wikipedia.org/wiki/ Learning through play, diakses 16 Agustus 2016 
dan pertimbangan dari pihak sekolah. Selanjutnya rancangan manual tersebut kemudian dirubah ke koding atau source codemenggunakan Macromedia Flash versi 8. Proses perekaman audio untuk mengisi suara pada aplikasi menggunakan alat perekam otomatis yang dapat merubah jenis suara raw menjadi berekstensi mp3. Untuk materi bahasa Inggris tingkat dasar, pengabdi sesuaikan dengan kurikulum atau materi bahasa Inggris dari sekolah yang telah pengabdi terima pada saat langkah pengumpulan data (sebelum networking).

Untuk perekaman audio sendiri membutuhkan alat dan strategi yang baik agar pengerjaan cepat dan meminimalisir kesalahan dalam pembacaan pada saat perekaman. Perekaman dilakukan di ruang LBKI fakultas Dakwah dan Komunikasi UIN Walisongo. Proses perekaman kali ini menggunakan peralatan recorder merk tertentu. Hasil dari perekaman menggunakan recorder ini adalah file audio berekstensi mp3.Ruangan tersebut mempunyai dinding yang kedap suara sehingga dimungkinkan meminimalisir noise atau gangguan yang muncul. Noise yang muncul dapat berupa suara apapun yang tiba-tiba masuk pada saat proses perekaman, seperti suara orang berbicara, bunyi kendaraan yang sedang melintas, bunyi detik jam, dan sebagainya.

Untuk menghilangkan noise yang tiba-tiba masuk ke hasil rekaman, tidak perlu mengulang kembali proses perekaman. Hasil rekaman tersebut dapat di edit dengan menggunakan Adobe Audition. Pada KPD ini menggunakan Adobe Audition versi 1.5. Adobe Audition versi 1.5 merupakan salah satu versi software untuk semua komputer 32 bit. Semua jenis Adobe sangat membutuhkan space (ruang) di harddisk yang cukup besar mengingat versi Adobe digunakan untuk pengolahan audio, video dan image. Untuk Adobe Audition ini membutuhkan temporary space yang cukup besar untuk editing file audio, biasanya Adobe akan secara otomatis menyarankan drive $\mathrm{D}$ atau $\mathrm{E}$ (jika mempunyai 3 drive yaitu $\mathrm{C}$, D, E) yang mempunyai space kosong lebih besar.

Pengerjaan perancangan diawali dari rancangan atau design dari pengabdi. Guru di TK tempat pengabdian berlangsung,bertugas untuk memberikan masukan terutama agar rancangan gambar dan aplikasi sesuai dengan metode pembelajaran learning by playing. Setelah perancangan selesai dilanjutkan dengan merubah desain tersebut ke dalam bahasa pemrograman (coding). Coding atau koding dilakukan dengan menggunakan Macromedia Flash 8. Berikut ini beberapa tampilan rancangan gambar latar untuk aplikasi bahasa Inggris dengan menggunakan metode Learning by Playing. 


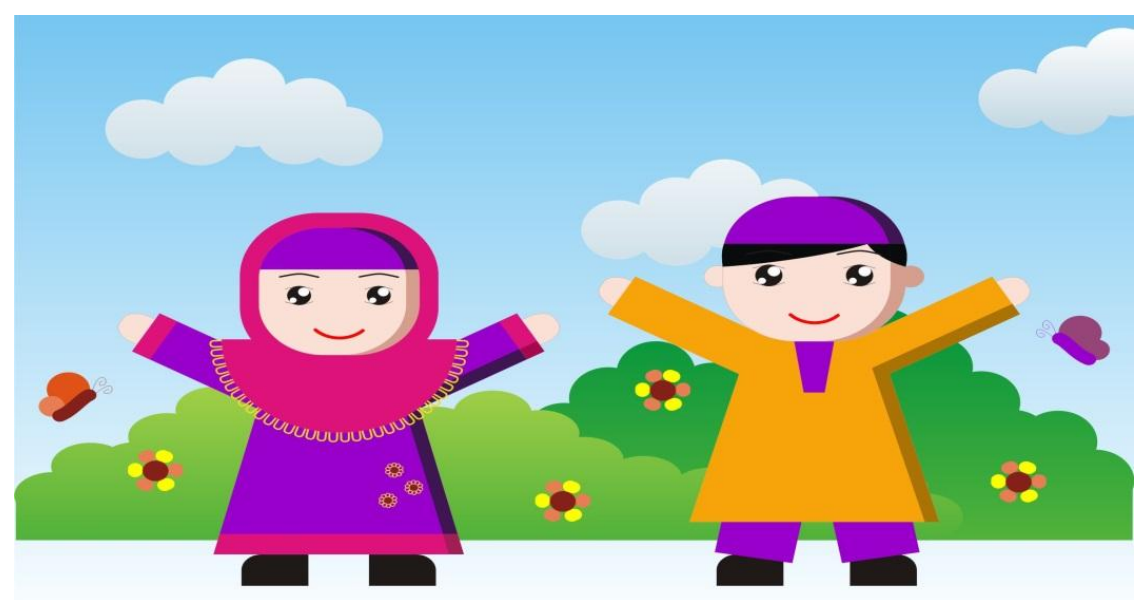

Gambar 1. Gambar Latar Pertama

Gambar latar pertama terdiri dari 2 anak yaitu seorang laki-laki dan perempuan berhijab. Gambar tersebut memperlihatkan ke dua anak tersebut berada di tempat terbuka. Tempat terbuka ditunjukkan adanya tanaman hijau, langit berwaran biru cerah, awan putih berarak dan kupu-kupu berterbangan. Kedua anak tersenyum ceria sambil di mengangkat ke dua tangan namun tidak melakukan aktifitas permainan. Gambar latar pertama memang dibuat minimalis sebab gambar latar ini dipergunakan untuk tampilan menu awal. Sebagai menu awal, gambar ke dua anak ini akan tertutup oleh semua menu yang ada dari menu greeting hingga classroom.

Gambar latar kedua memperlihatkan ada 2 anak yaitu seorang anak lakilaki dan seorang anak perempuan berhijab yang sedang bermain di taman atau tempat terbuka. Taman tersebut mempunyai 2 buah alat permainan yaitu ayunan dan prosotan. Anak perempuan tersebut sedang bermain ayunan sambil memandang kupu-kupu yang berterbangan. Sedangkan anak laki-laki di taman tersebut sedang bermain bola sambil tersenyum ceria. Gambar latar kedua di rancang dengan suasana ceria, banyak pohon-pohon rindang, semak-semak berbunga, langit biru cerah, awan berarak beriringan, kupu-kupu cantik berwarna warni terbang bersliweran. Adanya 2 mainan di taman menunjukkan bahwa dunia anak TK tidak jauh dari dunia permainan. Warna juga dipilih cerah dan berkesan ceria sehingga anak-anak akan nyaman dan senang dalam menggunakan aplikasi ini. Latar belakang pohon dan taman di pilih karena selain mewakili dunia anak-anak juga menyimpan misi lain yaitu agar anak-anak menyayangi tanaman dan pohon yang mulai menipis jumlahnya di Indonesia. 


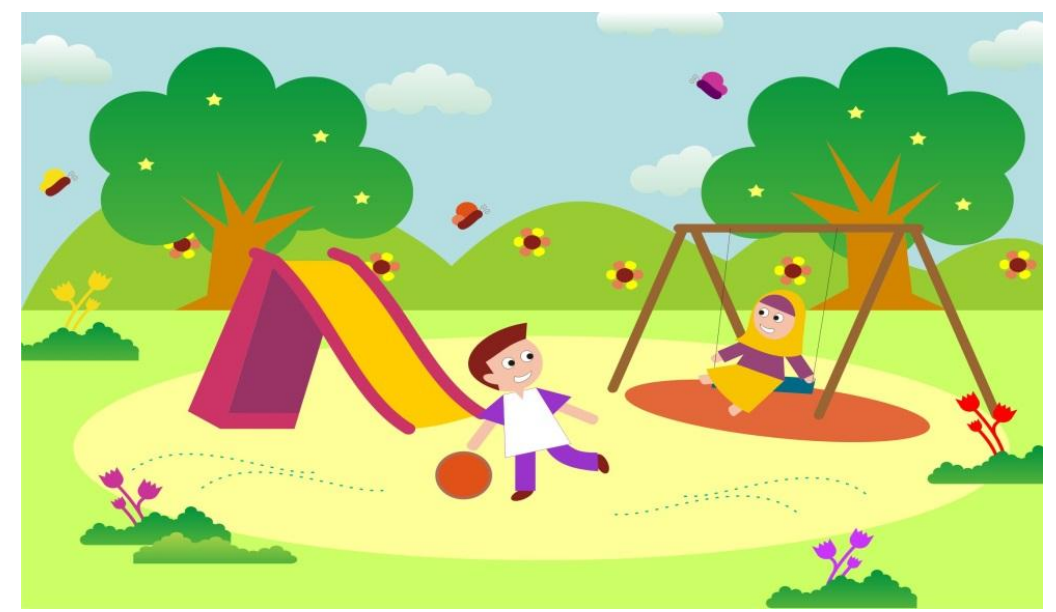

Gambar 2 Gambar Latar Kedua

Setelah perancangan oleh pengabdi maka selanjutnya dilakukan koordinasi dengan pihak sekolah untuk menselaraskan rancangan awal yang telah dibuat. Pihak sekolah tidak keberatan dengan rancangan gambar yang telah dibuat namun untuk materi bahasa Inggris, pihak sekolah memberikan masukan yang sangat baik.Materi bahasa Inggris yang disepakati ada 8 bagian yaitu greeting/salam, numbers/angka, colours/warna, buman body/anggota tubuh, animals/hewan, days/hari, months/bulan dan classroom/ruang kelas. Untuk salam ada 4 macam yaitugood morning, good afternoon, good evening dan good night. Untuk angka dimulai dari angka one hingga twenty. Untuk warna ada ada 10 yaitu white, black, purple, red, blue, pink, yellow, orange, brown, grey dan green.

Untuk human body ada hair, eye, nose, ear, finger, arm, foot, mouth, stomach dan shoulder. Sedangkan animal ada ant, bird, buffalo, cat, cockroach, cow, crocodile, duck, deer, eagle, dog, fish, giraffe, lion, goat, lizard, goldfish, monkey, scorpion, snake, tiger, termite, mouse dan swan. Untuk daysdi mulai dari Sunday, Monday, Tuesday, Wednesday, Thursday, Friday, dan Saturday. Sedangkan untuk months di mulai dari January, February, March, April, May, June, July, August, September, October, November dan December. Classroom terdiri dari bag, book, belt, chair, blackboard, hat, pencil, table, shoes, trouser, skirt, uniform, wall, whiteboard dan window.

Berikut ini adalah tampilan awal dari aplikasi bahasa Inggris dengan menggunakan metode Learning by Playing. Menu awal menggunakan gambar latar pertama. 


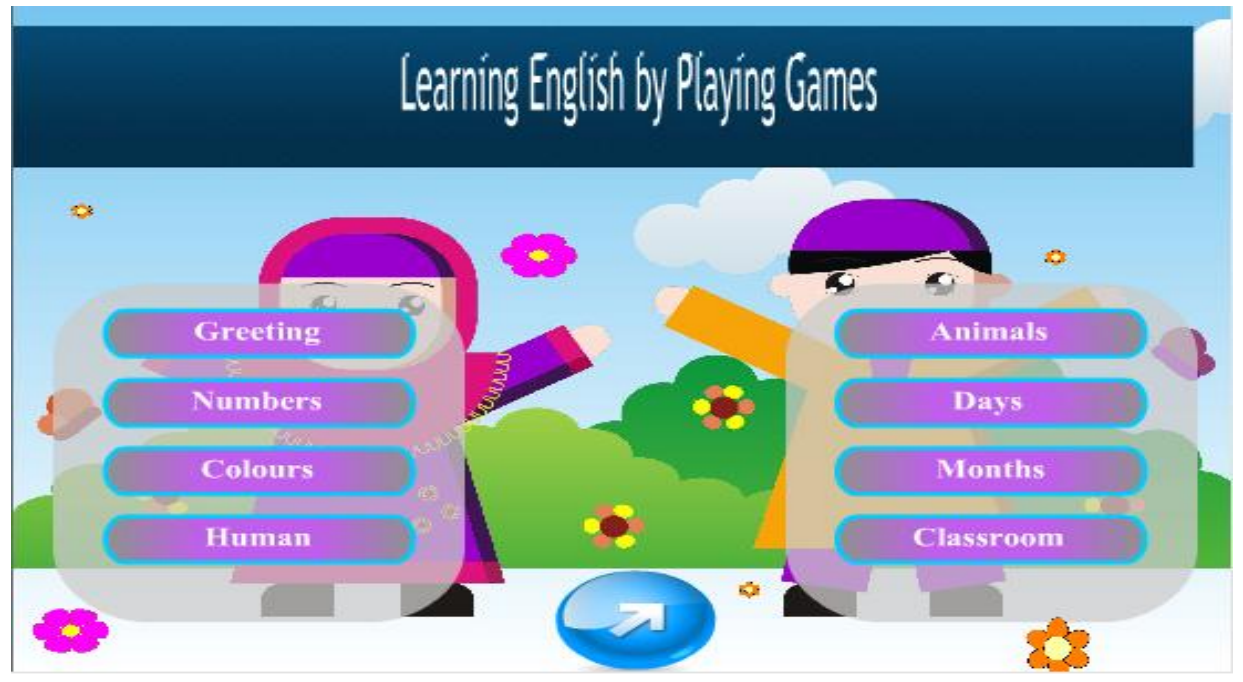

Gambar 3. Menu Utama

Gambar di atas adalah menu awal yang akan ditampilkan pertama kali pada user atau siswa TK. Pemilihan materi telah disesuaikan dengan kurikulum ekstra kurikuler bahasa Inggris tingkat dasar yaitu di mulai dari greeting dan diakhiri dengan classroom. Bentuk huruf kemudian gambar latar disesuaikan dengan metode learning by playingyaitu berwarna cerah dan jelas tulisannya sehingga memudahkan anak TK untuk belajar. Pada metode learning by playing, anak-anak diharapkan dapat belajar melalui permainan.

Anak-anak sekarang cenderung menyukai gadget. Mereka lebih pandai dalam menyelesaikan permainan atau game dibanding orang dewasa, baik game yang dimainkan di handphone, tablet, komputer atau laptop maupun menggunakan playstation atau xbox. Oleh sebab itu aplikasi bahasa Inggris ini dibuat agar dapat ditampilkan di laptop untuk mempermudah pembelajaran. Guru dapat mengajar dengan menggunakan media laptop dan LCD proyektor untuk memperbesar tampilan.

Sub menu aplikasi ini seperti greeting, numbers, colour dan lainnya menggunakan fungsi klik pada teks (on click) dan tidak berurut. Pembelajaran secara tidak berurut berfungsi untuk mempermudah user dalam belajar. Seorang user dapat belajar materi di sub menu greeting kemudian berpindah ke materi months kemudian dapat berpindah ke materi buman dan seterusnya, hal ini karena metode yang digunakan bukan metode berjenjang (seperti level pada game) namun menggunakan metode acak atau random. Cara seperti ini tidak mempersulit siswa TK untuk belajar sehingga mereka akan menikmati proses 
belajar karena seolah-olah mereka tidak belajar namun bermain, itulah konsep metode learning by playing.

Apabila menu Greeting di klik maka akan muncul tampilan baru yang menunjukkan ada 4 pilihan menu greeting seperti yang terlihat pada gambar di bawah 4 .

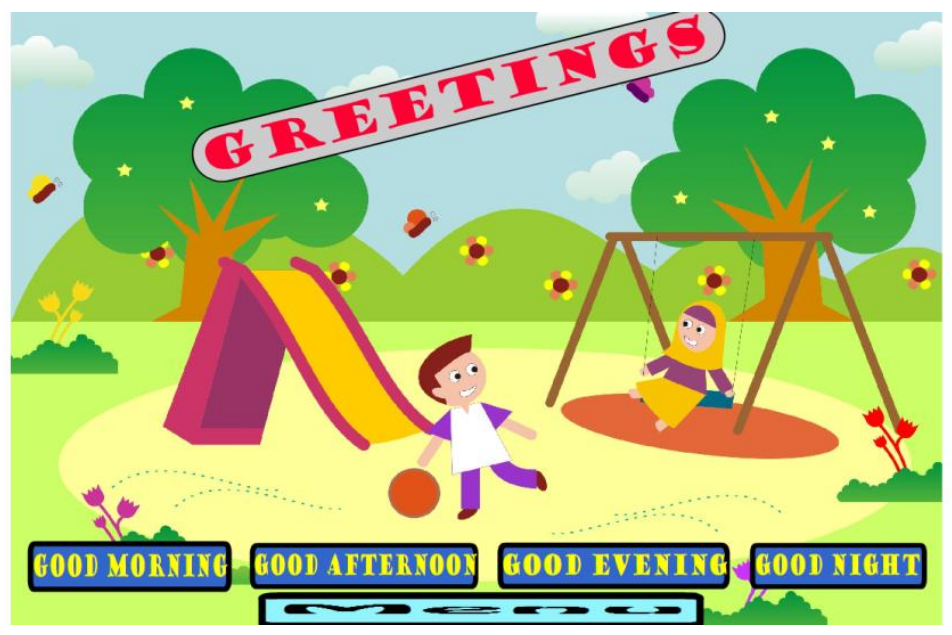

Gambar 4. Menu Greeting

Pada menu greeting, proses pembelajaran tidak terurut dari kiri ke kanan atau kanan ke kiri. User dapat mengklik button secara acak (tidak harus berurut). Pada menu greeting tersebut jika salah satu button di klik, misalnya sub menu good morning (selamat pagi) maka akan muncul tampilan baru sebuah gambar yang mewakili suasana pagi yaitu ayam jantan berkokok dan terdengar suara "/good môrniNG/".

Perhatikan bahwa setiap kali pointer kursor menyorot objek maka objek tersebut akan berwarna berbeda (highlight) untuk mempermudah user mengingat di posisi mana pointer kursor berada. Pada menu greeting ini highlight berwarna hitam.

Tahap ketiga, Pengujian. Fase terpenting dalam sebuah pembuatan aplikasi ataupun program adalah pengujian. Pada kegiatan pengabdian ini karena menghasilkan sebuah produk aplikasi berupa pembelajaran yang berbentuk permainan (game) maka produk tersebut juga harus melalui pengujian. Menurut Widyanahar terdapat 5 pengujian (yaitu pengujian unit, integrasi, beta, regresi dan stress) untuk sebuah pekerjaan berbasis bahasa pemrograman/script. Dari ke 5 pengujian yang sudah disebutkan hanya 4 pengujian yang dibutuhkan. Untuk pengujian ke 5 yaitu pengujian stres tidak diperlukan sebab aplikasi ini adalah 
berbentuk game bukan aplikasi sistem informasi yang membutuhkan kehandalan sebuah sistem dalam menangani sebuah pekerjaan multitasking. Pengujian yang digunakan meliputi 1) Pengujian unit, untuk pengujian ini adalah mendengarkan satu per satu file audio kemudian di cek terdapat kesalahan bacaan atau tidak, atau terdapat noise yang mengganggu atau tidak. Jika dalam pengujian terdapat ketidaksesuaian maka harus diulang kembali. Pengulangan tidak perlu secara keseluruhan, cukup hanya yang terkena noise.Jika tidak ingin diulang maka lakukan editing untuk penghilangan noise. Selain pengujian audio, pengujian yang terpenting lainnya adalah pengujian koding aplikasi.Salah sedikit saja dalam memberikan koding maka akan berakiat fatal pada sebuah program. Macromedia flash menggunakan layer dan frame dalam proses pembuatan, oleh sebab itu untuk pengujian unit dilakukan per layer dan per scene. Apabila per layer dan per scene tidak menemui kendala atau tanpa kesalahan (error) maka dilakukan pengujian gabungan atau integrasi.

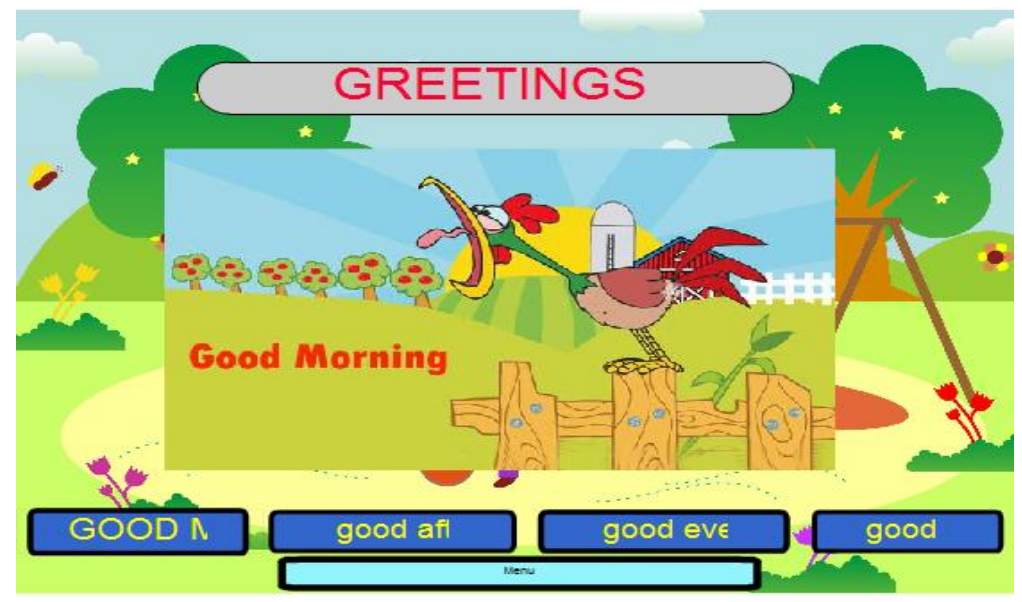

Gambar 5 Sub Menu Greeting

Pengujian selanjutnya, 2) Pengujian integrasi, pengujian dilakukan ketika beberapa scenedigabungkan/dijalankan menjadi satu. Jika pada saat dilakukan penggabungan scene terdapat error maka harus dilakukan pembetulan dimana letak kesalahan koding yang menyebabkan error. Setelah perbaikan koding maka harus dilakukan pengujian unit dan integrasi kembali. Jika tidak ditemukan error maka dapat dilakukan pengujian selanjutnya yaitu beta.

Kemudian 3) berupa Pengujian beta, pengujian ini adalah pengujian yang dilakukan di hadapan para guru dan kepala sekolah. Pada pengujian ini 
membutuhkan masukan atau feedback dari para guru dan kepala sekolah. Yang mana jika terdapat masukan untuk perbaikan kualitas aplikasi pembelajaran bahasa Inggris dengan metode learning by playing maka harus dilakukan sebelum diimplementasikan ke anak didik (siswa TK). Jika tidak ada masalah maka pengujian dilanjutkan pada pengujian regresi.

Pengujian yang terakhir, 4) Pengujian regresi, pengujian terakhir untuk kegiatan pengabdian ini adalah regresi. Pengujian yang dilakukan pada saat implementasi terhadap siswa TK. Sebenarnya siswa juga berhak memberikan masukan mengingat siswalah yang akan menggunakan, namun karena siswa pada kegiatan pengabdian ini adalah anak TK maka masukan hanya seputar warna dan gambar.

Tahap keempat, Pelatihan guru, siswa dan sosialisasi orang tua. Setelah kegiatan perancangan, pembuatan, pengujian dan editing aplikasi maka langkah selanjutnya dari kegiatan ini adalah pelatihan bagi guru TK. Pelatihan dilaksanakan pada hari Jumat dan Sabtu. Pemilihan hari Jumat dan sabtu dikarenakan pada kedua hari tersebut kegiatan proses belajar mengajar (PBM) tidak sepadat hari Senin hingga Kamis. Demi kelancaran PMB dan pelatihan, diputuskan semua kegiatan pengabdian dilaksanakan hari Jumat dan Sabtu setiap minggunya.

Pelaksanaan hari Jumat tanggal 5 Agustus 2016 dilaksanakan dari pukul 10.00 hingga 15.00 secara bergantian. Ada 2 gelombang dalam kegiatan pelatihan pengabdian ini. Walaupun jumlah guru sebagai peserta sedikit namun tetap dilaksanakan dalam 2 gelombang. Hal ini dikarenakan Jumat adalah hari kerja/sekolah maka sebagian guru tetap melaksanakan pengajaran pada pukul 10.00 hingga 12.00. Sedangkan guru yang lain melaksanakan kegiatan pengabdian pada pukul $13.00-15.00$.

Pelatihan gelombang pertama berlangsung selama kurang lebih 2 jam (dari pukul 10.00 - 12.00) diikuti pengabdi beserta sukarelawan sebanyak 4 orang dan 2 guru serta seorang staf. Pelatihan diawali dengan pengenalan aplikasi oleh pengabdi selama kurang lebih 30 menit. Pengenalan aplikasi di mulai dari tampilan awal dengan 8 menu dari greeting hingga classroom. Ke 8 menu disesuaikan dengan kurikulum TK tersebut. Pada pelatihan ini ke 8 menu dicoba satu per satu, dimulai dari greeting dan berakhir pada classroom. Pada kenyataannya dalam menggunakan aplikasi ini tidak harus dimulai dari greeting kemudian numbers, colours dan seterusnya, namun dapat dilakukan secara acak atau random. Acak artinya user dapat menggunakan aplikasi ini dimulai dari menu apa saja, seperti diawali dari numbers kemudian berpindah ke classroom kemudian ke animals dan sebagainya. 
Para guru diberi kebebasan untuk berlatih selama 1 jam dengan didampingi pengabdi. Disela-sela latihan para guru dapat menanyakan kesulitan atau kendala yang dialami pada saat mencoba aplikasi. Selain mencoba, guruguru tersebut juga dipersilahkan untuk bertanya dan memberi masukan yang kemungkinan terlewat pada saat pengujian dan editing.

Setelah masa pelatihan dan pendampingan selama 1 jam selesai, maka para guru diberi waktu selama 30 menit untuk berlatih secara mandiri dari awal membuka aplikasi hingga keluar dari aplikasi. Selama latihan mandiri tersebut tidak ada kendala yang berarti hanya saja para guru tersebut terlihat belum terbiasa menggunakan piranti perangkat keras atau laptop. Kesan takut melakukan kesalahan jelas sangat terlihat dari para guru tersebut.

Ketakutan tersebut adalah jika melakukan kesalahan dalam menekan tombol maka akan menyebabkan rusaknya aplikasi. Padahal aplikasi yang di coba adalah aplikasi dalam bentuk "publish" sehingga tidak akan merusak script atau koding yang ada. Script bisa berubah jika para guru membuka aplikasi source kemudian mengubah scriptnya atau menghapus file yang berekstensi .fla. Pada pelatihan guru, pada saat melakukan penjelasan bagian file yang dapat menyebabkan aplikasi hilang karena terhapus, dibutuhkan kehati-hatian ekstra dalam menjelaskan. Hal tersebut dikarenakan para guru tersebut belum familiar dengan pengarsipan atau penyimpanan file, terlebih jika harus membedakan ekstensi file.

Pukul 12.00-13.00 kegiatan pengabdian berhenti untuk melaksanakan sholat dhuhur berjamaah dan makan siang bersama. Selama kegiatan istirahat tersebut berlangsung, guru-guru yang sudah berpraktik dan staf yang melihat cukup antusias untuk bertanya tentang aplikasi. Dimungkinkan dengan adanya aplikasi ini maka struktur kurikulum dapat berubah, sebab aplikasi ini mempermudah proses belajar mengajar ekstrakurikuler. Perubahan dimungkinkan dengan menambah materi pembelajaran yang lain seperti nama bunga atau buah-buahan.

Tepat pukul 13.00 WIB kegiatan pengabdian dilanjutkan kembali dengan peserta pelatihan 2 guru yang lain. Mekanisme pelatihan sama dengan pelatihan guru sebelumnya. Perbedaan pelatihan yang kelompok 2 ini adalah keseluruhan guru beserta staf dapat mengikuti pelatihan. Hal tersebut disebabkan proses belajar mengajar siswa telah usai.Walaupun keseluruhan guru dapat mengikuti pelatihan, namun fokus pengabdi tetap pada guru yang belum mencoba aplikasi sama sekali. Fokus pengabdian diperlukan agar tujuan dari pengabdian tercapai yaitu pemanfaatan secara maksimal aplikasi bahasa Inggris dengan metode 
Learning by doing ini oleh guru-guru di TK tersebut untuk mempermudah pembelajaran ekstrakurikuler bahasa Inggris.

Pelatihan hari Sabtu tanggal 6 Agustus 2016, diikuti oleh siswa dan siswi TK kelas B (usia 5 hingga 6 tahun). Pemilihan siswa kelas B karena kelas inilah yang diajarkan mata pelajaran bahasa Inggris sebagai mata pelajaran ekstrakurikuler. Alasan ekstra kurikuler bahasa Inggris hanya diajarkan pada kelas B sebab kelas ini adalah kelas dengan usia tertua dari kelas lain di TK tersebut. Kelas dengan usia lebih tua tentunya mempunyai daya nalar yang lebih baik dari siswa dengan usia dibawahnya.

Peserta pelatihan hari Sabtu berjumlah 22 siswa TK kelas B. Siswa dibentuk menjadi 5 kelompok dengan masing-masing 4-5 orang siswa. Setiap kelompok terdapat satu laptop yang sudah terinstal aplikasi Learning bahasa Inggris. Masing-masing kelompok didampingi oleh satu guru. Pelatihan untuk siswa TK membutuhkan waktu yang lebih lama sekitar 4 jam, dari jam 08.0012.00 .

Lamanya waktu yang dibutuhkan untuk pelatihan siswa TK disebabkan harus melakukan adaptasi piranti perangkat keras dahulu terhadap siswa TK. Pelatihan di mulai dengan menjelaskan apa itu laptop beserta bagian-bagian dari laptop. Setelah penjelasan selesai maka dimulai pelatihan aplikasi. Reaksi yang diperlihatkan siswa TK terhadap aplikasi tersebut menggembirakan. Siswa TK menyukai animasi yang muncul pada aplikasi. Terlihat dari komentar yang diucapkan pada saat pelatihan. Pemilihan gambar latar juga mempengaruhi keasyikan siswa TK untuk belajar sambil bermain.

Kemudahan penggunaan aplikasi terlihat dari kemudahan siswa dalam mengulang materi yang dirasa kurang paham. Apabila siswa kurang memahami pronounciation yang diucapkan maka mereka cukup mengklik ulang button (tombol) materi tersebut.Dimisalkan pada pelatihan classroom (ruang kelas). Ketika siswa mengklik button bergambar kursi (chair) dan terdengar pronounciation"/cher/" namun siswa tersebut kurang jelas mendengar maka untuk mengulang pronounciation tersebut siswa hanya tinggal mengklik ulang button chair tersebut, tidak perlu keluar dari aplikasi (logout).

Setelah pelatihan guru dan siswa selesai, langkah selanjutnya adalah sosialisasi terhadap orang tua atau wali siswa. Sosialisasi bertujuan untuk memperkenalkan adanya metode pembelajaran baru yaitu learning by doing untuk pelajaran ekstra kurikuler bahasa Inggris tingkat dasar. Sosialisasi dihadiri guru, staf, perwakilan orang tua siswa dan pengabdi beserta mahasiswa dan sukarelawan sebanyak 29 orang. Sosialisasi dilaksanakan hari Selasa tanggal 9 
Agustus dimulai pukul 12.00. Pemilihan waktu pukul 12.00 sebab acara diawali dengan sholat Dhuhur berjamaah, selain itu agar kegiatan PBM tidak terganggu.

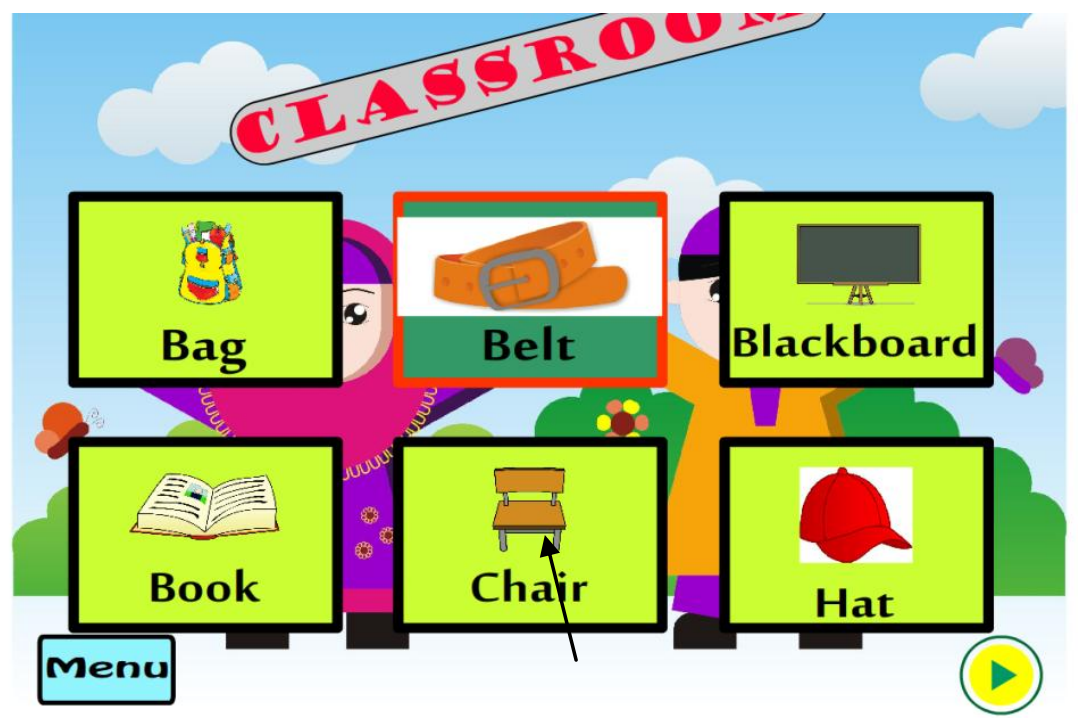

Gambar 4. Pelatihan Siswa dengan Button Chair

Setelah sholat berjamaah, acara didahului dengan pembukaan dan sambutan dari pihak sekolah. Pada kegiatan tersebut, pihak sekolah menjelaskan tujuan diadakannya pertemuan dan manfaat dari aplikasi bahasa Inggris menggunakan metode Learning by Doing. Disebabkan aplikasi ini adalah hasil dari kegiatan KPD (karya pengabdian dosen) UIN Walisongo Semarang maka aplikasi ini tidak membutuhkan adanya pungutan biaya bagi orang tua/wali siswa. Setiap siswa diberikan cd (compact disc)aplikasi secara cuma-cuma sehingga siswa juga dapat belajar di rumah dengan orang tua atau wali siswa.

Pengabdi beserta mahasiswa dan sukarelawan, secara bergantian menayangkan bagaimana cara kerja aplikasi melalui LCD proyektor, agar para orang tua atau wali siswa dapat mengoperasikan di rumah. Orang tua atau wali siswa sangat antusias dan memberikan penghargaan yang baik dengan inovasi pembelajaran baru ini. Selain itu mereka juga mengajukan pertanyaan dan memberikan masukan yang berhubungan dengan aplikasi tersebut. Pertanyaan yang diajukan seputar garansi atau jaminan jika cd aplikasi tidak bisa digunakan selain itu juga jaminan untuk diberikan bantuan pembelajaran jika orang tua atau wali siswa lupa cara menggunakan. Sedangkan masukan yang diberikan adalah mereka mengharapkan adanya aplikasi yang serupa untuk mata pelajaran lain, 
jika memungkinkan. Atau orang tua berharap adanya tutorial atau rekaman video untuk mata pelajaran lain, mengingat mereka tidak diperbolehkan menunggu anak mereka di sekolah sehingga mata pelajaran apapun yang diberikan di sekolah, mereka kurang memahaminya.

Tahap kelima, Monitoring. Setelah aplikasi ini diimplementasikan di TK ABA 62 dan kegiatan sosialisasi selesai dilakukan, pengabdi tetap berusaha untuk selalu mengawasi dan mengevaluasi terhadap perkembangan kegiatan KPD tersebut. Kegiatan monitoring sekaligus sebagai bahan evaluasi bagi pengabdi dalam melaksanakan kegiatan KPD. Monitoring dilaksanakan setiap hari Sabtu selama 4 kali yaitu tanggal 13, 20 dan 27 Agustus diakhiri 3 September 2016.

Monitoring hari pertama yaitu Sabtu tanggal 13 Agustus, siswa diperkenalkan materi greeting. Siswa diminta untuk mengulangi setiap pengucapan yang di dengar. Apabila ada salah satu atau beberapa siswa yang salah dalam pengucapan maka guru akan memutar ulang bagian tersebut dan meminta siswa untuk mengulang pengucapan.

Monitoring hari ke dua yaitu Sabtu tanggal 20 Agustus, sebelum mendengarkan materi numbers, siswa diminta untuk mengulang pelajaran minggu lalu. Setelah pengulangan pelajaran minggu lalu selesai, siswa diajarkan materi numbers. Sama seperti kegiatan monitoring pertama, siswa diminta untuk mengulangi setiap pengucapan yang di dengar. Apabila ada salah satu atau beberapa siswa yang salah dalam pengucapan maka guru akan memutar ulang bagian tersebut dan meminta siswa untuk mengulang pengucapan.

Monitoring hari ke tiga yaitu Sabtu tanggal 27 Agustus, sebelum mendengarkan materi colours, siswa diminta untuk mengulang pelajaran minggu lalu. Setelah pengulangan pelajaran minggu lalu selesai, siswa diajarkan materi colours. Sama seperti kegiatan monitoring pertama dan kedua, siswa diminta untuk mengulangi setiap pengucapan yang di dengar. Apabila ada salah satu atau beberapa siswa yang salah dalam pengucapan maka guru akan memutar ulang bagian tersebut dan meminta siswa untuk mengulang pengucapan.

Monitoring hari terakhir yaitu Sabtu tanggal 3 September, sebelum mendengarkan materi buman body, siswa diminta untuk mengulang pelajaran minggu lalu (numbers). Setelah pengulangan pelajaran minggu lalu selesai, siswa diajarkan materi buman body. Sama seperti kegiatan monitoring sebelumnya, siswa diminta untuk mengulangi setiap pengucapan yang di dengar. Apabila ada salah satu atau beberapa siswa yang salah dalam pengucapan maka guru akan memutar ulang bagian tersebut dan meminta siswa untuk mengulang pengucapan.

Selama empat kali proses monitoring, pengabdi hanya dapat memantau hingga human body. Meskipun begitu monitoring tetap pengabdi lakukan melalui 
telpon atau teks pesan baik sms atau wa untuk memonitoring sub menu yang lain. Secara garis besar, pengabdi dapat melihat bahwa aplikasi telah dijalankan dengan baik oleh guru. Siswa TK juga dapat memahami bahasa Inggris tingkat dasar dengan mudah menggunakan aplikasi tersebut. Bisa dikatakan baik guru dan siswa tidak menemui kendala dalam menggunakan aplikasi.

\section{KESIMPULAN}

Bagi sekolah TK yang memiliki keterbatasan baik sumber daya manusia dan finansial, dalam proses belajar mengajar hendaknya hindari menggunakan metode konvensional.Gantilah metode konvensional dengan menggunakan metode yang lebih praktis namun sesuai sasaran. Sasaran dari sekolah TK tentunya adalah siswa TK. Anak TK dengan usia rentang 4 hingga 6 tahun mempunyai dunia yang berbeda dengan usia sekolah lainnya. Dunia anak-anak usia TK adalah dunia bermain. Untuk menciptakan suasana belajar yang menyenangkan akan lebih baik jika dalam belajar dipadukan dengan bermain. Metode yang memadukan antara belajar dan bermain adalah learning by playing.

Metode learning by playing ini diterapkan pula dalam membuat aplikasi yang menunjang PBM ekskul bahasa Inggris tingkat dasar. Oleh sebab itu aplikasi yang dibuat baik dari gambar latar, tulisan, gambar untuk merepresentasikan obyek bahkan warna yang dipilih sesuai dengan dunia anak-anak agar mereka nyaman dan senang dalam belajar.Pembelajaran dengan menggunakan metode learning by playing adalah pembelajaran yang membuat anak-anak dapat memahami sebuah pelajaran yang diajarkan dengan cara menggunakan permainan. Hal tersebut disebabkan inti dari metode ini adalah anak-anak dapat aktif terlibat dalam permainan, mampu mengeksplorasi diri dalam memperoleh pelajaran baru, dan mau untuk sering berlatih dan mengulang keterampilan dan merasa senang dengan semua kegiatan yang dilibatinya terutama berhubungan dengan mata pelajaran yang sedang dipelajarinya.

\section{DAFTAR PUSTAKA}

Anonim, 2014, Taman Kanak-kanak, https://id.wikipedia.org/wiki/ Taman_kanak-kanak, diakses 2 Maret 2016 Anonim, UU dan RUU/UUD45, http://dpr.go.id/uu-dan-ruu/uud45, diakses 2 Maret 2016 
Anonim, 2015, Wajib TK sebelum Masuk SD, http://www.jpnn.com/read/2015/06/19/310452/Mulai-2016,-Wajib-TKSebelum-Masuk-SD, diakses 2 Maret 2016

Anonim, 2016, Ajar, http://kbbi.web.id/ajar, diakses 2 Agustus 2016

Anonim, 2011, Apa Macromedia Flash dan Sejarah Flash, http:/ /ilmuti.com/2011/10/18/apa-macromedia-flash-dan-sejarah-flashitu/, diakses 28 Juli 2016

Anonim, 2016, Bahasa Inggris, https://id.wikipedia.org/wiki/Bahasa_Inggris, diakses 16 Agustus 2016

Anonim, 2010, Corel, https://edugrafs.files.wordpress.com/2010/07/2.jpg, diakses 10 Agustus 2016

Anonim, 2010, Världens 100 största språk 2010 (100 Bahasa Terbesar Dunia pada 2010), National Encyklopedin

Anonim, 2015, Pengertian-pengertian Info, http://pengertian-pengertianinfo.blogspot.co.id/2015/11/pengertian-dan-tinjauan-tentang_12.html

Anonim, 2016, Learning Through Play, https://en.wikipedia.org/wiki/ Learning through play, diakses 16 Agustus 2016

Anonim, 2016, Ilmu Pengetahuan : Situs Web Belajar Online, http:/ / www.organisasi.org/1970/01/arti-singkatan-spp-kepanjangan-darispp-kamus-akronim-bahasa-indonesia.html, di akses 18 Agustus 2016

Cheshire, Jenny, 1991, English Around The World: Sociolinguistic Perspectives, Cambridge University Press, doi : 10.2277/0521395658, ISBN 0-52139565-8

Crystal, David, 2002, Language Death, Cambridge University Press, doi:10.2277/0521012716, ISBN 0-521-01271-6.

Fanani, Ahmad Zainul, 2007, Membuat Presentasi Multimedia Menggunakan Macromedia Flash Pro 8, Elex Media Komputindo, Jakarta

Graddol, David, 2000, The Future of English? A Guide to Forecasting the Popularity of the English Language in the 21st Century . The British Council. hal 10

Hjarvard, Stig, 2004, The globalization of Language: How the Media Contribute to the Spread of English and the Emergence of medialects, Trans. Charly Hultén. Nordicom Review

J. Schmidhuber, 2010, Graphics: English replacing German as language of Science Nobel Prize winners, Evolution of National Nobel Prize Shares in the 20th Century at arXiv:1009.2634v1

Kahn, Jack, and Wright, Susan Elinor, Human growth and the development of personality, Pergamon Press, ISBN 978-1-59486-068-3

Lewis, M.Paul, Gary F., Simons, Fennig, Charles D. (ed.), Ethnologue: Languages of the World, Ethnologue (18th ed.), Dallas, Texas: SIL International

Mydans, Seth, 2007, Across cultures, English is the Word, The New York Times

Noviana, Nur Anisa, 2003, Jenjang Pendidikan Formal Di Indonesia Menurut UndangUndang Sistem Pendidikan Nasional Tabun 2003, http://ilmu- 
pendidikan.net/pendidikan/peraturan/jenjang-pendidikan-formal-diindonesia-uu-sisdiknas-2003, diakses 2 Maret 2016

Oxford Learner's Dictionary, 2015, English - Pronunciation, Oxford University

Perdana, Destya Arya, 2013, Pengertian dan Fungsi Corel Draw, http:/ cyberspaceinformation.blogspot.co.id/2013/05/pengertian-dan-fungsi-coreldraw_3451.html, diakses 10 Agustus 2016

Smith, Ross, 2005, Global English: Gift or Curse?, English Today21 (2): 56, doi:10.1017/S0266078405002075

Sutopo, Ariesto Hadi, 2002, Animasi dengan Macromedia Flash, Salemba Infotek, Jakarta

Thabrani, Suryanto, Ir., MM., 2003, Movie dan Game : Compyter Graphics dengan Flash MX, Salemba Infotek, Jakarta

Tirtarahardja, Umar. 2005. Pengantar Pendidikan. Jakarta: Rineka Cipta

Wahyono, Budi, Jalur dan Jenjang Pendidikan Menurut UU Sisdiknas, http://www.pendidikanekonomi.com/2012/12/jalur-dan-jenjangpendidikan-menurut-uu.html, diakses 2 Maret 2016

Weissbort, Daniel, 2006, Translation: Theory and Practice : a historical reader, hal 100, Oxford University Press

Wijaya, Didik, 2002, Macromedia Flash 5.0 dengan ActionScript, Elex Media Komputindo, Jakarta 
